\title{
OBSERVATIONS ON THE C.S.F. PRESSURE DURING COMPRESSSION OF THE JUGULAR VEINS
}

\author{
By D. A. J. Tyrrell, M.B., Ch.B., M.R.C.P. \\ University Dept. of Medicine, Royal Hospital, Sheffield
}

It is often noted that the rise of C.S.F. pressure in response to compression of the jugular veins is variable and unpredictable. While doing routine lumbar punctures it was noticed that the amount of pressure rise seemed to depend on the side on which the patient was lying, and this report describes a study made to extend this observation.

The subjects were 12 ward patients in whom there was no reason to suspect an abnormality of the circulation. of the C.S.F. or of the cerebral veins. Lumbar puncture was performed in the left lateral position with a wide gauge needle (17-18 S.W.G. externally) and the pressure was recorded in a manometer of internal diameter about $2 \mathrm{~mm}$. The patient rested until the pressure reached a steady reading. Compression was applied for 5 seconds by the fingers passed round the neck from behind and the pressure at the end of this time was recorded to the nearest $0.5 \mathrm{~cm}$. The observation was repeated until a constant response was obtained. The patient was moved to the right lateral, and sometimes the sitting position and the measurement was repeated.

TABLE I

C.S.F. Pressure Responses in Subject I

\begin{tabular}{c|c|c}
\hline $\begin{array}{c}\text { Position of } \\
\text { Patient }\end{array}$ & \multicolumn{2}{|c}{ Rise on Compression of- } \\
\cline { 2 - 3 } & $\begin{array}{c}\text { Right Jugular } \\
\text { Vein }\end{array}$ & $\begin{array}{c}\text { Left Jugular } \\
\text { Vein }\end{array}$ \\
\hline Right lateral $\cdots$ & $5.0 \mathrm{~cm}$. & $1.0 \mathrm{~cm}$. \\
\hline Left lateral $\ldots$ & $0.5 \mathrm{~cm}$. & $5.0 \mathrm{~cm}$. \\
\hline
\end{tabular}

Two main findings emerge: firstly, the amount of pressure rise depends on posture and changes with it. Table I illustrates this and shows how the rise in C.S.F. pressure is greater if a vein next to the bed is compressed (e.g. left jugular vein compression-rise greater in left lateral than right lateral position). The C.S.F. pressure responses on compression of the individual jugular veins with the subjects in the two lateral positions were $\$$ therefore compared in each of the 12 patients. In 응 19 instances the rise was greater when the vein was next to the bed when compressed (average difference $3.2 \mathrm{~cm}$.), in two instances the rise was $0.5 \mathrm{~cm}$. less in this position, and in three instances no difference was observed. In the sitting posi $\vec{\theta}$ tion the rise of pressure on compression of eace $G$ jugular vein was smaller than in the horizontati position. The average rise was 48 per cent? (S.E. 8 per cent.) of the mean of the rises on compressing the same vein in the two lateral positions. Table 2 gives the various findings in one of the patients.

Secondly, in most cases the rise is consistently greater on compression of one side of the neck than on compression of the other, though the amount of the rise is modified by posture as described in the preceding paragraph. In II of the cases this effect was seen to some extent and in 8 of them the right side showed the greater rise (Table 2) (Gardner, 1944). The resting pressure was in all cases lower in the right lateral position.

TABLE 2

C.S.F. Pressure Responses in Subject 2

\begin{tabular}{ll|l|l|l}
\hline $\begin{array}{c}\text { Position of } \\
\text { Patient }\end{array}$ & \multicolumn{2}{|c}{$\begin{array}{c}\text { Rise on Compression } \\
\text { of- }\end{array}$} & $\begin{array}{c}\text { Resting } \\
\text { Pressure }\end{array}$ \\
\cline { 3 - 5 } $\begin{array}{c}\text { Right } \\
\text { Jugular } \\
\text { Vein }\end{array}$ & $\begin{array}{c}\text { Left } \\
\text { Jugular } \\
\text { Vein }\end{array}$ & \\
\hline Right lateral & $\ldots$ & $11.0 \mathrm{~cm}$. & $0.5 \mathrm{~cm}$. & $17.5 \mathrm{~cm}$. \\
\hline Left lateral & $\ldots$ & $5.5 \mathrm{~cm}$. & $2.0 \mathrm{~cm}$. & $25.0 \mathrm{~cm}$. \\
\hline Sitting $\ldots$ & $\ldots$ & $3.5 \mathrm{~cm}$. & $1.0 \mathrm{~cm}$. & $37.0 \mathrm{~cm}$. \\
\hline
\end{tabular}


The rate of rise when both veins were compressed seemed constant in all positions but was difficult to measure accurately with this technique. Finally, when compression was continued over a period longer than 5 seconds on one side only, the effect of posture was similar to that observed during shorter periods of compression.

\section{Discussion}

The following is a suggested explanation of some of these phenomena. The rises in pressure are believed to be due to the production of cerebral venous congestion. Gravity has a large influence on the return of blood from the head. If changing from one lateral position to the other transfers part of the venous return from one jugular vein to the other then the amount of rise of C.S.F. pressure on compressing one vein should alter correspondingly; though the rate of rise on compressing both veins should be constant in all positions. Both these suggestions seem to fit the facts.

The area of brain drained by each of the jugular veins is usually unequal, and as the right vein usually drains the larger area it usually carries a greater blood flow. It would therefore be expected that the rise of pressure on right jugular compression would usually be greater than that on left jugular compression. This also fits the findings.

It is recommended (Price, 1947) that the right jugular vein only be compressed in doing the Queckenstedt test. If in a patient such as that recorded in Table 3 lumbar puncture were performed in the left lateral position and only the right jugular vein were compressed, a subarachnoid spinal block might be unjustifiably suspected. This would occur more often if the left jugular vein were compressed in the right lateral
TABLE 3

C.S.F. Pressure Responses in Subject 3

\begin{tabular}{cc|c|c}
\hline $\begin{array}{c}\text { Position of } \\
\text { Patient }\end{array}$ & \multicolumn{2}{|c}{ Rise on Compression of - } \\
\cline { 2 - 3 } & $\begin{array}{c}\text { Right Jugular } \\
\text { Vein }\end{array}$ & $\begin{array}{c}\text { Left Jugular } \\
\text { Vein }\end{array}$ \\
\hline Right lateral $\cdots$ & $2.5 \mathrm{~cm}$. & $0.5 \mathrm{~cm}$. \\
\hline Left lateral $\quad \ldots$ & 0 & $3.0 \mathrm{~cm}$. \\
\hline
\end{tabular}

position (two of the present series). In testing for spinal subarachnoid block one should, therefore, always compress the jugular vein on the side next to the bed.

\section{Summary}

I. In normal subjects in the lateral positions the rise of C.S.F. pressure on compression of a single jugular vein is usually greater when the vein compressed is on the side next to the bed.

2. Rises on compressing a particular jugular vein may be greater than those on compressing the other, whatever the patient's position. In this case it is usually compression of the right jugular vein which gives the greater rise.

3. The asymmetrical responses are probably due to irregularities of the venous return on the two sides, in the case of (I) due to the effect of gravity, and in the case of (2) due to one vein (commonly the right) draining a greater proportion of the brain than the left.

\section{Acknowledgments}

I wish to thank Professor C. H. Stuart-Harris, Dr. A. W. D. Leishman, Professor E. J. Wayne and Dr. E. Skipper for permission to test their patients, and Dr. C. E. Davies for valuable criticism.

\section{BIBLIOGRAPHY}

PRICE, F. W. (1947), 'A Textbook of the Practice of Medicine,' 8th edition, 1611 .

GARDNER, W. J. (1944), ' Medical Physics,' Year Book Pub. Co., 151 . 